\title{
Strategi Pengembangan Usaha Ikan Nila Salina (Oreochromis sp.) Sebagai Varietas Baru Budidaya Perikanan
}

\author{
Development Strategy of Salina Tilapia (Oreochromis sp.) Culture as New Varieties of Aquaculture
}

\author{
Kiki Mariya Dewi ${ }^{*}$, Aida Vitayala S Hubeis ${ }^{2 \sharp}$, dan Sapta Raharja ${ }^{3 \#}$ \\ ${ }^{1}$ Badan Pengkajian dan Penerapan Teknologi \\ *Gedung 612 LAPTIAB Puspiptek, Serpong, Tangerang Selatan 15314 \\ ${ }^{2}$ Departemen Komunikasi dan Pengembangan Masyarakat Fakultas Ekologi Manusia, IPB \\ ${ }^{3}$ Departemen Teknologi Industri Pertanian Fakultas Teknologi Pertanian, IPB \\ \#Jl. Kamper Kampus IPB Darmaga Bogor 16680
}

\begin{abstract}
ABSTRAK
Salina merupakan benih ikan nila hibrida toleran salinitas tinggi hasil perbaikan genetik yang mampu berkembang dan tumbuh di perairan payau dengan kadar garam $>20$ ppt atau bahkan di perairan laut dengan salinitas hingga 32ppt melalui pemanfaatan karakter euryhaline yang dimiliki ikan nila. Salina secara resmi telah dirilis oleh Kementerian Kelautan dan Perikanan pada Maret 2014 berdasarkan Keputusan Menteri Kelautan dan Perikanan Republik Indonesia Nomor 22/KEPMEN-KP/2014 Tentang Pelepasan Ikan Nila Salina dengan nama komersil Salina (Saline Tolerance Indonesian Tilapia). Penelitian ini bertujuan untuk mengidentifikasi kelayakan finansial serta faktor internal dan eksternal usaha Salina dalam rangka menyusun strategi pengembangan usaha budidaya ikan nila Salina. Metode yang digunakan adalah analisis deskriptif kuantitatif yang terdiri dari matriks Internal Factor Evaluation (IFE), External Factor Evaluation (EFE), Internal-External (IE), Strength-Weakness-Opportunities-Threats (SWOT), dan dengan metode pengambilan keputusan Analytic Hierarchy Process (AHP). Instrumen yang digunakan dalam analisis finansial adalah Break Even Point (BEP), Net Present Value (NPV), Internal Rate of Return (IRR), Net Benefit Cost Ratio (B/C Ratio), dan Payback Periode (PP). Berdasarkan analisis finansial, usaha Salina dinyatakan layak. Perolehan hasil dari perhitungan IFE adalah 2,18 dan EFE adalah 3,10, menempatkan posisi usaha Salina pada sel II. Hasil penilaian AHP menyatakan prioritas alternatif strategi adalah melakukan kegiatan promosi dan sosialisasi untuk memperkenalkan Salina sekaligus menarik minat masyarakat dan meningkatkan permintaan.
\end{abstract}

Kata kunci: budidaya perikanan, ikan nila Salina, strategi pengembangan

\section{ABSTRACT}

Salina is a high salinity tolerant hybrid tilapia seed of genetic improvement that can grow well in brackish water that has salinity more than 20ppt or even in marine water with salinity up to 32ppt through the utilization of character euryhaline tilapia. Salina has been oficially by the Ministry of Marine Affairs and Fisheries in March 2014 based on the Decree of the Minister of Marine Affairs and Fisheries of the Republic of Indonesia Number 22/KEPMEN-KP/2014 on the Release of Salina Tilapia with commercial name Salina (Saline Tolerance Indonesian Tilapia). This study aimed to identify the financial feasibility as well as internal and external Salina culture factors in order to formulate the development strategy of Salina tilapia culture. The method used was quantitative descriptive analysiswhich consists of a matrix Internal Factor Evaluation (IFE), External Factor Evaluation (EFE),Internal-External (IE), Strength-Weakness-Opportunities-Threats(SWOT), andAnalytic Hierarchy Process (AHP) as a decisionmaking methods. The instruments used in the financial analysis were BEP, NPV, IRR, Net B/C Ratio, and PP. Based on financial analysis, Salina culture was feasible. While the result of the calculation of IFE is 2.18 and EFE is 3.10, positioning the Salina cell II. The results of the AHP assessment stated that the

\footnotetext{
*) Korespondensi:

Gedung 612 LAPTIAB Puspiptek, Serpong, Tangerang Selatan 15314; email: kikimdewi@ymail.com
} 
strategic priority of the strategy was to conduct promotional and socialization activities to introduce Salina as well as to attract public interest and increase demand.

Key words: development strategy, salina tilapia, varieties of aquaculture

\section{PENDAHULUAN}

Budidaya ikan nila di Indonesia sudah dikenal sejak tahun 1970-an. Seiring dengan perkembangan teknologi budidaya dan pemuliaan ikan, berbagai penelitian terus dilakukan untuk mendapatkan varietas ikan nila yang unggul. Sampai saat ini, di Indonesia telah beredar lebih dari 10 varietas ikan nila unggul hasil pemuliaan dan perbaikan genetik. Budidaya ikan nila telah dilakukan dalam berbagai sistem budidaya yang berbeda (kolam tanah, kolam beton, kolam air deras, dan jaring apung), dengan berbagai strategi pengelolaan (secara ekstensif, semi intensif atau intensif, monokultur, polikultur, monoseks, dan campuran) serta di lingkungan yang berbeda (air tawar dan air payau) (Altun et al., 2006). Selain itu, Penyebaran ikan nila yang begitu cepat didukung dengan kemampuan cepat matang gonad (Ayuningtyas et al., 2015) serta reproduksi yang tinggi (Mantau, 2005) menyebabkan perkembangan ikan nila tidak terkontrol.

Sebagai salah satu bentuk komitmen BPPT (Badan Pengkajian dan Penerapan Teknologi) dalam mendukung pengembangan perikanan nasional, pada tahun 2012 BPPT menghasilkan prototip ikan nila Salina. Salina secara resmi telah dirilis oleh Kementerian Kelautan dan Perikanan pada Maret 2014 berdasarkan Keputusan Menteri Kelautan dan Perikanan Republik Indonesia Nomor 22/KEPMEN-KP/2014 Tentang Pelepasan Ikan Nila Salina dengan nama komersil Salina (Saline Tolerance Indonesian Tilapia). Salina merupakan benih ikan nila hibrida toleran salinitas tinggi hasil perbaikan genetic yang mampu berkembang dan tumbuh di perairan payau dengan kadar garam >20ppt atau bahkan di perairan laut dengan salinitas hingga 32 ppt melalui pemanfaatan karakter euryhaline yang dimiliki ikan nila. Proses pemijahan untuk menghasilkan Salina dilakukan di lingkungan payau, sehingga benih Salina yang dihasilkan telah teradaptasi di lingkungan payau. Kemampuan adaptasi nila pada air asin telah menjadi bahan perhatian yang cukup luas (Ridha, 2008). Keistimewaan Salina adalah memiliki pertumbuhan yang cepat pada salinitas optimal (>20 ppt), tingkat sintasan (kelangsungan hidup) tinggi, nilai FCR (Feed Conversion Ratio) rendah, dan tahan terhadap serangan penyakit yang disebabkan oleh bakteri Streptococcus sp.

Salina merupakan solusi untuk permasalahan tambak idle dan marjinal di kawasan pantura akibat kerusakan lingkungan maupun karena efek pemanasan global. Perubahan lingkungan perairan akibat pemanasan global menyebabkan naiknya permukaan air laut, air tanah menjadi lebih asin, dan lahan persawahan di kawasan pesisir tergenang air laut sehingga menyebabkan semakin bertambahnya luas lahan payau dengan tingkat salinitas yang semakin meningkat. Salinitas air tambak dapat mencapai $40 \mathrm{ppt}$, terlebih saat musim kemarau. Ikan nila sudah terbukti mampu tumbuh dengan baik pada salinitas tinggi bahkan di laut (Morita et al., 2004). Oleh karena itu, kemampuan adaptasi nila pada air asin telah menjadi bahan perhatian yang cukup luas (Ridha, 2008). Ikan nila menawarkan solusi bagi pemanfaatan lahan marjinal tersebut dengan kemampuannya yang telah terbukti dapat tumbuh dengan baik pada salinitas tinggi. Salina sebagai varietas baru budidaya dengan penyebarannya yang masih terbatas merupakan usaha potensial yang memiliki beberapa kendala yang perlu disiasati dengan strategi yang tepat, sehingga dapat berkembang dan memiliki daya saing serta nilai jual tinggi.

Dalam mengembangkan usaha budidaya Salina diperlukan analisis mendalam untuk mengetahui kondisi eksisting usaha Salina, faktorfaktor eksternal dan internal yang berpengaruh dalam perumusan strategi pengembangannya. Langkah-langkah yang diperlukan untuk menyusun strategi pengembangan usaha Salina adalah melakukan analisis kelayakan usaha dengan mengelompokkan komponen yang termasuk manfaat dan komponen biaya untuk menyusun aliran tunai. Penyusunan ini untuk mengetahui kelayakan investasi secara finansial dan beberapa manfaat bersih yang diperoleh. Dalam bagian ini, komponen manfaat dan biaya dibatasi hanya pada biaya dan manfaat yang dapat dikuantifikasi (Sismaraini, 2015). Serta melakukan analisis terhadap kondisi eksisting usaha budidaya Salina melalui identifikasi faktor-faktor internal dan eksternal yang berpengaruh dalam usaha budidaya Salina. 
Penelitian ini bertujuan untuk mengidentifikasi kelayakan finansial serta faktor internal dan eksternal usaha Salina dalam rangka menyusun strategi pengembangan usaha budidaya ikan nila Salina.

\section{METODE PENELITIAN}

Penentuan subjek penelitian atau responden dalam penelitian ini dilakukan dengan cara purposive sampling dikombinasikan dengan snowball sampling. Pengumpulan data dilakukan pada bulan Januari-Juni 2017 di beberapa lokasi sesuai dengan lokasi kerja responden dan pakar atau pemangku kepentingan yang terkait. Lokasi pengumpulan data dan informasi terkait dengan usaha budidaya Salina, yaitu (1) BPIATLWU merupakan lokasi perekayasaan Salina dan pengembangan induk Salina; (2) BLUPPB merupakan lokasi pengujian Salina, perbanyakan benih dan induk sekaligus menjadi lokasi pengembangan budidaya Salina; (3) Kelompok Alam Lestari; (4) Kelompok Lestari merupakan kelompok petani tambak udang dan ikan nila di Pantura; (5) PTPP merupakan unit kerja di BPPT yang melakukan program perekayasaan Salina; dan (6) DJPB merupakan instansi pemerintah bagian dari KKP yang terkait dengan kegiatan budidaya perikanan.

Jenis data yang digunakan dalam penelitian ini terdiri dari data primer dan data sekunder. Data primer diperoleh melalui observasi terhadap mitra pengembang Salina melalui wawancara mendalam dan pengisian kuesioner kepada para pakar dan pelaku usaha ikan nila. Kuesioner penelitian terdiri dari 3 bagian, yaitu (1) Strengths, Weakneses, opportunities, dan Threats (SWOT); (2) Internal Factor Evaluation (IFE) dan External Factor Evaluation (EFE); dan (3) Analytic Hierarchy Process (AHP). Data sekunder didapatkan dari bukubuku, publikasi dari instansi pemerintah (Badan Pusat Statistik, Badan Pengkajian dan Penerapan Teknologi, dan Kementerian Kelautan dan Perikanan), jurnal nasional maupun jurnal internasional, laporan penelitian yang terkait dengan Salina, serta dokumen-dokumen lain yang relevan.

Penentuan responden berdasarkan tingkat kepakarannya yang dianggap cukup ahli dan menguasai permasalahan yang ditanyakan. Wawancara mendalam dilakukan untuk mendapatkan infprmasi kondisi terkini dan gambaran umum usaha Salina. Kuesioner digunakan sebagai alat untuk mendapatkan informasi terkait dengan strategi pengembangan usaha Salina, yaitu faktor eksternal dan internal yang berpengaruh serta masukan lain yang berguna dalam merumuskan strategi pengembangan usaha Salina.

Metode pengolahan dan analisis data terdiri atas analisis deskriptif dan input data menggunakan analisis kuantitatif. Analisis kelayakan finansial menggunakan perhitunganperhitungan kriteria investasi yaitu, Break Even Point (BEP), Net Present Value (NPV), Internal Rate of Return (IRR), Net Benefit Cost Ratio (B/C Ratio), dan Payback Periode (PP). Tahapan selanjutnya adalah identifikasi faktor internal dan eksternal dengan metode matriks IFE dan EFE. Matriks IFE digunakan untuk menganalisis faktor internal usaha berupa kekuatan dan kelemahan. Matriks EFE digunakan untuk menganalisis faktor eksternal berupa peluang dan ancaman yang sedang dan akan dihadapi dalam menjalankan usaha budi daya Salina. Kemudian di tahap pemaduan digunakan alat analisis Internal-Eksternal (IE) dan matriks SWOT. Pada tahap penentuan keputusan strategi berdasarkan alternatif-alternatif strategi yang dirumuskan melalui analisis SWOT sebelumnya, akan dipilih berdasarkan skala prioritas (bobot) dari nalisis AHP. Penyelesaian metode AHP menggunakan aplikasi Super Decisions.

Dalam perhitungan kelayakan finansial terdapat beberapa perkiraan atau asumsi untuk memudahkan perhitungan. Adapun asumsi yang digunakan pada usaha budidaya Salina adalah:

1. Membuat skenario perhitungan analasis usaha Salina (semi intensif) dibandingkan dengan ikan nila hitam (tradisional), dengan pertimbangan bahwa ikan nila hitam masih mendominasi di daerah Pantura.

2. Umur usaha ditetapkan 10 tahun, dengan pertimbangan berdasarkan umur ekonomi tertinggi dari aset.

3. Penghitungan nilai sintasan menggunakan pendekatan perkiraan dengan cara mengalikan biomassa panen dengan size (dalam $1 \mathrm{~kg}$ terdapat berapa ekor ikan) ikan saat panen.

4. Harga yang digunakan diasumsikan konstan. Baik harga input maupun harga output dari kegiatan usaha budidaya salina. Harga yang digunakan dalam penelitian adalah harga yang berlaku ketika wawancara dengan pihak terkait.

5. Seluruh modal yang digunakan dalam semua kegiatan budidaya berasal dari modal sendiri. 
6. Tingkat discount rate untuk Discount Factor (DF) yang digunakan sebesar $7 \%$.

7. Biaya operasional diasumsikan dikeluarkan mulai tahun ke-0, karena persiapan proses budidaya Salina mulai dilakukan pada tahun tersebut.

8. Ketentuan pajak mengikuti ketentuan undang-undang nomor 46 Tahun 2013, yaitu tarif pajak penghasilan sebesar $1 \%$ dari omset yang didapat perusahaan bila penerimaan yang didapat perusahaan dibawah $\mathrm{Rp} 4,8$ miliar.

\section{HASIL DAN PEMBAHASAN}

\section{Analisis Finansial}

Analisis finansial dilakukan untuk mengetahui tingkat kelayakan usaha budidaya Salina saat ini atau dimasa yang akan datang. Berdasarkan asumsi dasar yang telah ditetapkan, maka dapat disusun asumsi perhitungan kelayakan usaha budidaya Salina dan nila hitam seperti dijelaskan pada Tabel 1.

\section{Analisis Kelayakan Investasi}

Analisis kelayakan investasi dilakukan melalui perhitungan terhadap beberapa parameter yang dapat digunakan untuk mengetahui kelayakan sebuah investasi, yaitu: Break Even Point (BEP), Net Present Value (NPV), Internal Rate of Return (IRR), Net Benefit Cost Ratio (B/C Ratio), dan Payback Periode (PP). Hasil dari perhitungan parameter tersebut dapat digunakan sebagai salah satu acuan pertimbangan dalam usaha budidaya
Salina khusunya (Tabel 2). Berdasarkan data analisis kelayakan investasi, dapat disimpulkan bahwa usaha budidaya Salina layak untuk dilakukan karena memenuhi kriteria-kriteria kelayakan yang telah ditentukan. Pada setiap kriteria kelayakan, Salina memiliki nilai yang lebih tinggi dibandingkan nila hitam.

\section{Analisis Matriks IFE}

Matriks IFE menganalisis faktor-faktor strategis internal yaitu faktor-faktor yang menjadi kekuatan dan kelemahan budidaya Salina. Hasil identifikasi kekuatan dan kelemahan dimasukkan sebagai faktor strategis internal yang kemudian diberi bobot dan rating (Tabel 3). Berdasarkan pemberian bobot dan rating pada faktor IFE, didapatkan nilai total perhitungan matriks sebesar 2,18. Karena skor bobot dibawah 2,50 berarti Salina berada pada posisi sedikit lemah secara internal.

\section{Analisis Matriks EFE}

Matriks EFE menganalisis faktor-faktor strategis eksternal yaitu faktor-faktor yang menjadi peluang dan hambatan dalam pengembangan usaha Salina. Perhitungan matriks EFE dimulai dengan memasukkan faktor-faktor eksternal utama berupa peluang dan ancaman, kemudian dilakukan pembobotan dan pemeringkatan pada masing-masing faktor-faktor eksternal tersebut, kemudian antara bobot dan peringkat tersebut dikalikan sehingga didapatkan hasil seperti pada Tabel 4, dimana didapatkan nilai total perhitungan matriks EFE sebesar 3,10. Karena skor bobot diatas 2,50 menandakan usaha memiliki respon yang sangat baik terhadap peluang dan ancaman.

Tabel 1. Asumsi perhitungan kelayakan usaha budidaya Salina dan nila hitam

\begin{tabular}{clccc}
\hline No & \multicolumn{1}{c}{ Uraian } & Salina (semi intensif) & Nila hitam (tradisional) & Satuan \\
\hline 1 & Luas tambak & 4,000 & 20,000 & $\mathrm{~m}^{2}$ \\
2 & Padat tebar & 7.00 & 0.70 & ekor/m² \\
3 & Jumlah benih (ekor) & 28,000 & 14,000 & $\mathrm{ekor}$ \\
& Jumlah benih (kg) & - & 110 & $\mathrm{~kg}$ \\
4 & Harga benih per ekor & 175 & - & - \\
& Harga benih per kg & - & 30,000 & $\mathrm{Rp} / \mathrm{kg}$ \\
5 & Lama pemeliharaan & 120 & 135 & $\mathrm{hari}$ \\
6 & Siklus & 3 & 3 & $\mathrm{kali}$ \\
7 & FCR & 1.00 & 0.43 & \\
8 & Sintasan (\%) & 85 & 40 & $\mathrm{e}$ \\
& Sintasan (ekor) & 23,800 & 5,600 & $\mathrm{ekor}$ \\
9 & Ukuran panen & $3-4$ & $3-4$ & $\mathrm{~kg}$ \\
& Total biomassa panen & 6,800 & 1,400 & $\mathrm{~kg}$ \\
10 & Total pakan (pelet) & 6,800 & 600 & $\mathrm{Rp}$ \\
11 & Harga pakan & 8,000 & 10,000 & $\mathrm{Rp}$ \\
12 & Harga jual per kg & 14,000 & 17,000 &
\end{tabular}


Tabel 2. Analisis kelayakan investasi

\begin{tabular}{|c|c|c|c|c|}
\hline \multirow{2}{*}{\multicolumn{2}{|c|}{ No Perhitungan }} & \multirow{2}{*}{ Uraian } & \multicolumn{2}{|c|}{ Jenis Budidaya } \\
\hline & & & Salina & Nila Hitam \\
\hline \multirow[t]{2}{*}{1} & BEP Unit & Ekor & 4,902 & 1,066 \\
\hline & BEP Rupiah & Rupiah & $9,571,564$ & $5,281,644$ \\
\hline 2 & Net Present Value $\quad(\mathrm{NPV}, \mathrm{DF} 7 \%)$ & $\mathrm{NPV}>0(\mathrm{Rp})$ & $331,624,005$ & $54,869,832$ \\
\hline 3 & Internal Rate of Return & IRR>DF (\%) & 23.57 & 9.99 \\
\hline 4 & Net Benefit-Cost Ratio & Net $\mathrm{B} / \mathrm{C}>1$ & 1.20 & 1.12 \\
\hline \multirow[t]{2}{*}{5} & Payback Period $\quad(\mathrm{PP})$ & Tahun & 0.44 & 0.51 \\
\hline & Keterangan & & Layak & Layak \\
\hline
\end{tabular}

Tabel 3. Matriks IFE usaha budidaya Salina

\begin{tabular}{|c|c|c|c|}
\hline \multirow{2}{*}{ Faktor-Faktor Strategis Internal } & Bobot & Peringkat & Skor Bobot \\
\hline & $(\mathrm{A})$ & (B) & $(\mathrm{AxB})$ \\
\hline \multicolumn{4}{|l|}{ Kekuatan } \\
\hline Pertumbuhan Salina cepat & 0,09 & 3,78 & 0,35 \\
\hline Waktu pemeliharaan relatif singkat & 0,09 & 3,37 & 0,32 \\
\hline Tahan salinitas tinggi & 0,09 & 2,70 & 0,25 \\
\hline Mudah dibudidayakan & 0,08 & 3,18 & 0,25 \\
\hline Jumlah (A) & & & 1,16 \\
\hline \multicolumn{4}{|l|}{ Kelemahan } \\
\hline Nilai ekonomi Salina masih rendah & 0,10 & 2,05 & 0,21 \\
\hline Kurangnya jumlah SDM yang handal & 0,09 & 1,89 & 0,16 \\
\hline Pengendalian kualitas benih masih kurang & 0.09 & 2,00 & 0,19 \\
\hline Jumlah produksi benih Salina rendah & 0,09 & 1,52 & 0,14 \\
\hline Keterbatasan dalam penambahan jumlah induk & 0,10 & 2,00 & 0,20 \\
\hline Minimnya kegiatan promosi/sosialisasi & 0,09 & 1,32 & 0,12 \\
\hline Pendampingan & 0,08 & 2,00 & 0,16 \\
\hline Jumlah (B) & & & 1,02 \\
\hline Jumlah A+B & 1,00 & & 2,18 \\
\hline
\end{tabular}

Tabel 4. Matriks EFE usaha budidaya Salina

\begin{tabular}{|c|c|c|c|}
\hline \multirow{2}{*}{ Faktor-Faktor Strategis Eksternal } & \multirow{2}{*}{ Bobot } & \multirow{2}{*}{$\frac{\text { Peringkat }}{\text { (B) }}$} & \multirow{2}{*}{$\frac{\text { Skor Bobot }}{(\mathrm{AxB})}$} \\
\hline & & & \\
\hline \multicolumn{4}{|l|}{ Peluang } \\
\hline Banyaknya jumlah tambak marjinal di Pantura & 0,08 & 3,29 & 0,25 \\
\hline Banyak jumlah petani tambak aktif di Pantura & 0,08 & 2,77 & 0,23 \\
\hline Keinginan petani tambak beralih ke budidaya Salina & 0,10 & 2,05 & 0,20 \\
\hline Tingginya permintaan pasar akan ikan nila & 0,10 & 2,49 & 0,24 \\
\hline Mulai bermunculan usaha pengolahan ikan di Jawa Barat & 0,08 & 3,03 & 0,23 \\
\hline Terbukanya peluang pasar ekspor & 0,08 & 3,10 & 0,25 \\
\hline Jumlah (A) & & & 1,40 \\
\hline \multicolumn{4}{|l|}{ Ancaman } \\
\hline Budidaya ikan nila hitam masih mendominasi & 0,08 & 4,00 & 0,31 \\
\hline Harga pakan tinggi & 0,08 & 4,00 & 0,31 \\
\hline Harga jual ikan nila tambak rendah & 0,07 & 4,00 & 0,30 \\
\hline Kurangnya minat masyarakat terhadap nila warna merah & 0,08 & 4,00 & 0,34 \\
\hline $\begin{array}{l}\text { Keberlanjutan program dan pengembangannya tidak } \\
\text { terjamin }\end{array}$ & 0,09 & 2,00 & 0,18 \\
\hline Bencana alam (banjir) sulit dihindari & 0,09 & 3,00 & 0,27 \\
\hline Jumlah (B) & & & 1,70 \\
\hline Jumlah A+B & 1,00 & & 3,10 \\
\hline
\end{tabular}




\section{Matriks IE}

Berdasarkan hasil analisis matriks IFE dan EFE didapatkan nilai total skor terbobot faktor strategis internal sebesar 2,18 dan nilai total skor faktor strategis eksternal sebesar 3,10. Nilai tersebut kemudian dipetakan pada matriks IE (Gambar 1), untuk selanjutnya dilakukan analisis untuk mengetahui posisi industri dalam pemilihan alternatif strategi. Jika dipetakan pada matriks IE sebagaimana ditunjukkan pada Gambar 1, maka nilai tersebut berada pada sel II (Pertumbuhan) dengan strategi yang diterapkan adalah intensif (penetrasi pasar, pengembangan pasar, dan pengembangan produk) atau integratif (integrasi ke belakang, integrasi ke depan, dan integrasi horizontal). Strategi-strategi tersebut dianggap cocok karena pada tahap sebelumnya telah diidentifikasi faktor eksternal yang terdiri dari peluang dan ancaman apa saja yang memengaruhi kelangsungan usaha serta lingkungan internal yang terdiri dari kekuatan dan ancaman apa saja yang dapat memengaruhi kelangsungan usaha (Rahmawaty, 2016). Alternatif strategi yang dihasilkan tentunya akan membantu perusahaan dalam menghadapi persaingan dan menjaga kelangsungan usaha budidaya Salina.

\section{Analisis Matriks SWOT}

Analisis Matriks SWOT digunakan untuk memformulasikan alternatif strategi pengembangan usaha Salina berdasarkan kombinasi berbagai faktor internal dan eksternal yang telah diidentifikasi sebelumnya seperti yang dimuat dalam Gambar 2.

\section{Analisis Pemilihan Alternatif Strategi}

Hasil pengolahan dengan teknik AHP menunjukkan prioritas bobot sebagaimana disajikan pada Gambar 3. Hasil yang diperoleh dari analisis dengan teknik AHP ini cukup relevan dengan kondisi usaha Salina sekarang didasarkan pada analisis SWOT sebelumnya, bahwa dalam analisis kelemahan, terdapat kelemahan dalam hal promosi dan sosialisasi.

\section{Formulasi Strategi Pengembangan Usaha Salina}

Merujuk pada hasil analisis matriks internal eksternal, posisi usaha Salina berada pada sel II yang artinya usaha Salina berada dalam kondisi internal rata-rata dan eksternal tinggi (Rahmawaty, 2016). Menurut Rangkuti (2014) ada dua strategi dasar dari pertumbuhan pada tingkat korporat, yaitu konsentrasi pada satu industri atau diversifikasi ke industri lain. Jika memilih strategi konsentrasi, usaha dapat tumbuh melalui integrasi horizontal maupun vertikal, baik secara internal melaui sumber dayanya sendiri atau secara eksternal dengan menggunakan sumber daya dari luar. Apabila memilih strategi diversifikasi, maka usaha dapat tumbuh melalui konsentrasi atau diversifikasi konglomerat, baik secara internal melalui pengembangan produk baru, maupun eksternal melalui akuisisi atau joint ventures.

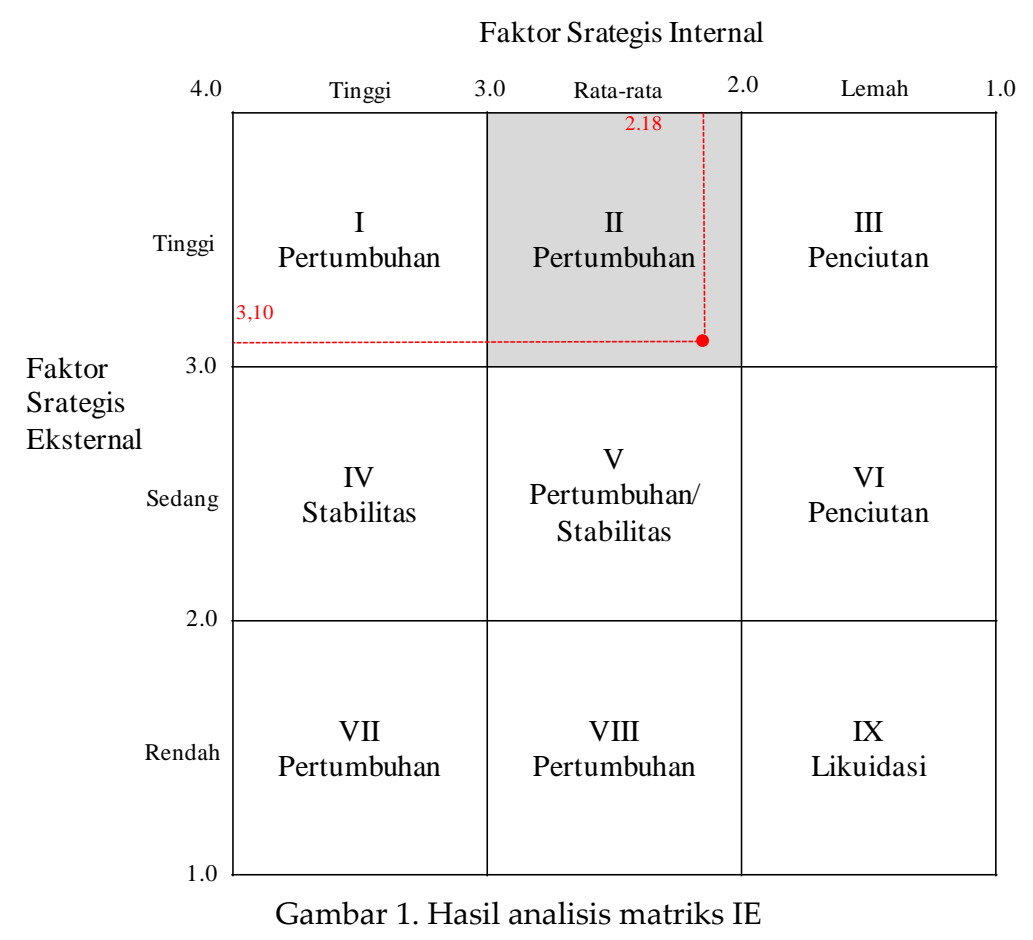




\begin{tabular}{|c|c|c|}
\hline Faktor Eksternal (EFAS) & $\begin{array}{l}\text { KEKUATAN (S) } \\
\text { 1. } \\
\text { Pertumbuhan Salina cepat } \\
\text { 2. } \text { Waktu pemeliharaan relatif } \\
\text { singkat } \\
\text { 3. } \text { Tahan salinitas tinggi } \\
\text { 4. } \\
\text { Mudah dibudidayakan }\end{array}$ & $\begin{array}{l}\text { KELEMAHAN (W) } \\
\text { 1. Nilai ekonomi Salina masih } \\
\text { rendah } \\
\text { 2. Kurangnya jumlah SDM yang } \\
\text { handal } \\
\text { 3. Pengendalian kualitas benih } \\
\text { masih kurang } \\
\text { 4. Jumlah produksi benih Salina } \\
\text { rendah } \\
\text { 5. Keterbatasan dalam jumlah induk } \\
\text { 6. Minimnya kegiatan promosi/ } \\
\text { sosialisasi } \\
\text { 7. Pendampingan teknologi } \\
\text { terhadap petani belum merata }\end{array}$ \\
\hline $\begin{array}{l}\text { PELUANG (O) } \\
\text { 1. Banyaknya jumlah tambak } \\
\text { marjinal di Pantura } \\
\text { 2. Banyak jumlah petani tambak } \\
\text { aktif di Pantura } \\
\text { 3. Keinginan petani tambak } \\
\text { beralih ke budidaya Salina } \\
\text { 4. Tingginya permintaan pasar } \\
\text { akan ikan nila } \\
\text { 5. Mulai bermunculan usaha } \\
\text { pengolahan ikan di Jawa Barat } \\
\text { 6. Terbukanya peluang pasar } \\
\text { ekspor }\end{array}$ & 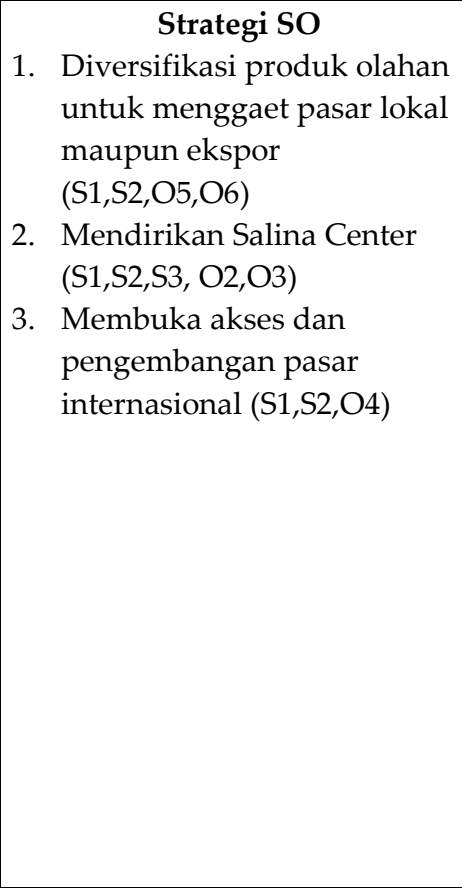 & $\begin{array}{l}\text { Strategi WO } \\
\text { 1. Menjalin kemitraan dengan petani } \\
\text { dan memberikan jaminan pasar } \\
\text { yang relatif stabil }(\mathrm{W} 1, \mathrm{O} 1, \mathrm{O} 2) \\
\text { 2. Mengintensifkan kegiatan } \\
\text { promosi dan sosialisasi untuk } \\
\text { memperkenalkan Salina sekaligus } \\
\text { menarikminat masyarakat dan } \\
\text { meningkatkan permintaan } \\
\text { (W6,O3,O4) } \\
\text { 3. Mengefektifkan kegiatan } \\
\text { pelatihan melalui transfer } \\
\text { teknologi kepada petani tambak } \\
\text { dengan menyiapkan tenaga ahli } \\
\text { sebagai pendamping (W2,W7,O2) } \\
\text { 4. Mengembangkan kerjasama } \\
\text { dengan industri dan himpunan } \\
\text { masyarakat tambak dalam rangka } \\
\text { mengoptimalkan pemanfaatan } \\
\text { lahan tambak dan penyebaran } \\
\text { Salina (W1,O1,O2,O3) }\end{array}$ \\
\hline $\begin{array}{l}\text { ANCAMAN (T) } \\
\text { 1. Budidaya ikan nila hitam } \\
\text { masih mendominasi } \\
\text { 2. Harga pakan tinggi } \\
\text { 3. Rendahnya harga jual ikan } \\
\text { nilai tambak } \\
\text { 4. Kurangnya minat masyarakat } \\
\text { terhadap nila warna merah } \\
\text { 5. Keberlanjutan program dan } \\
\text { pengembangannya tidak } \\
\text { terjamin } \\
\text { 6. Bencana alam (banjir) sulit } \\
\text { dihindari }\end{array}$ & \begin{tabular}{l}
\multicolumn{1}{c}{ Strategi ST } \\
Inovasi produk dengan \\
membuat Salina warna hitam \\
$(\mathrm{S} 1, \mathrm{~S} 2, \mathrm{~S} 3, \mathrm{~T} 1, \mathrm{~T} 4)$
\end{tabular} & \begin{tabular}{l}
\multicolumn{1}{c}{ Strategi WT } \\
1. Mengambil peran dalam program \\
pemerintah yang berkaitan \\
$(\mathrm{W} 1, \mathrm{~S} 5, \mathrm{~T} 1, \mathrm{~T} 2, \mathrm{~T} 5)$ \\
2. Menempatkan tenaga lapang \\
yang handal dan terampil \\
(W2,W3,T2,T6) \\
3. Memastikan keberlanjutan \\
program dan pengembangan \\
Salina (W1,W4,T5) \\
4. Meningkatkan jumlah produksi \\
benih dengan memperbanyak \\
ketersediaan induk \\
(W4,W5,T1,T4)
\end{tabular} \\
\hline
\end{tabular}

Gambar 2. Matriks SWOT alternatif strategi pengembangan usaha budidaya Salina 


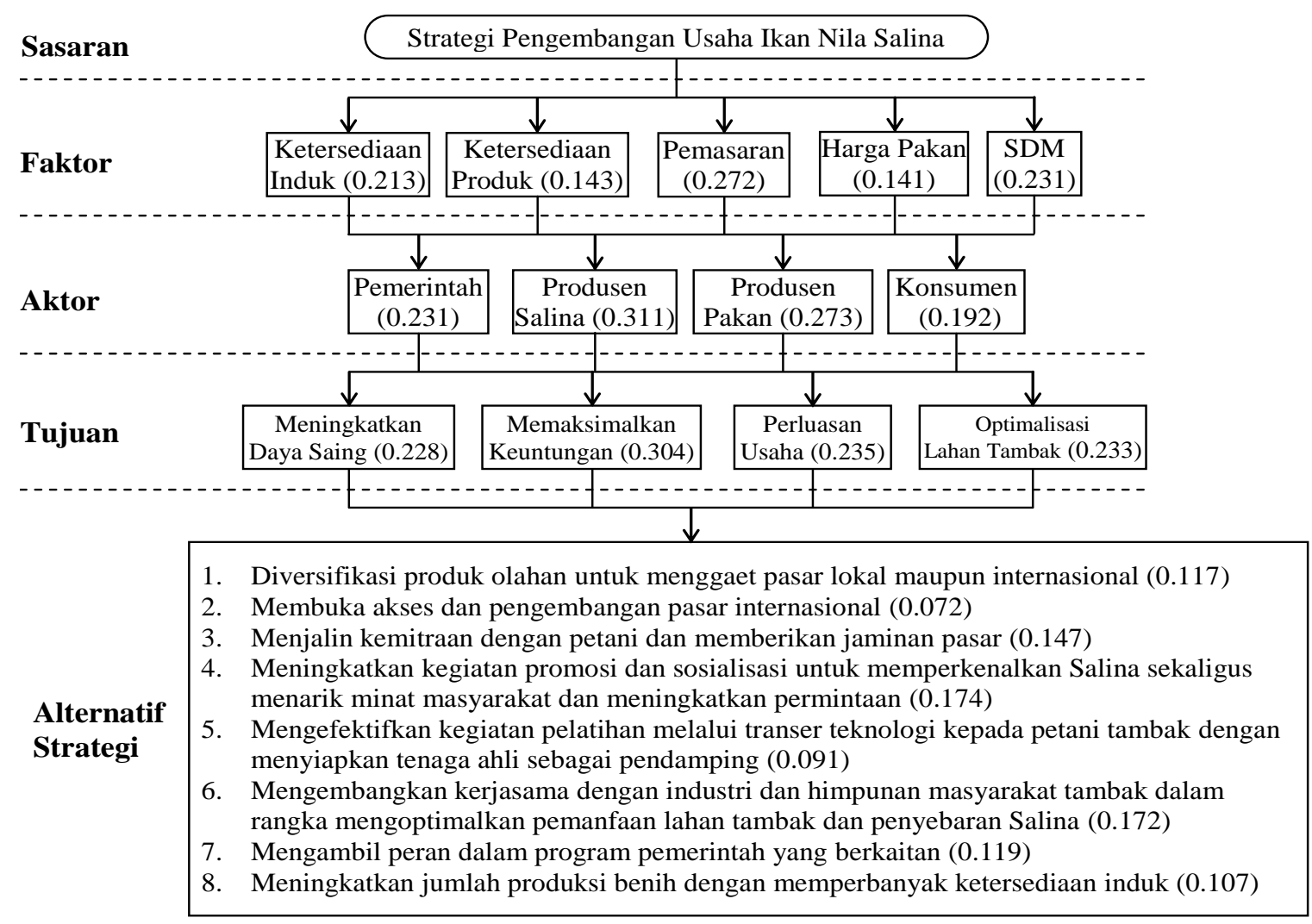

Gambar 3. Bobot hirarki pengembangan usaha Salina berdasarkan AHP

Berdasarkan dua analisis penentuan strategi pengembangan usaha Salina, maka dapat diformulasikan strategi, yaitu:

1. Penguatan usaha melalui penyelenggaraan pertemuan bisnis antar pemangku kepentingan terkait (industri/pengusaha dan masyarakat pembudi daya) dengan melibatkan pemerintah sebagai fasilitator. Tujuannya adalah agar terbentuk Memorandum of Understanding (MoU) atau nota kesepahaman antar pihak-pihak yang terlibat agar terdapat kepastian hubungan bisnis yang lebih mengikat dalam hal peningkatan pemasaran Salina, sehingga tercipta pasar untuk Salina yang lebih terjamin,

2. Meningkatkan pemasaran Salina dengan memperluas target pasar bukan hanya di kawasan Pantura dan membidik pasar internasional dengan melibatkan pemerintah dalam hal promosi dan sosialisasinya melalui pameran dan secara aktif memperkenalkan Salina di setiap pertemuan bertaraf nasional maupun internasional.

\section{KESIMPULAN}

Berdasarkan analisis kelayakan finansial, usaha budidaya Salina dinyatakan layak. Pengembangan usaha Salina dipengaruhi beberapa faktor internal dan eksternal. Faktor internal yang menjadi kekuatan Salina adalah tingkat pertumbuhan Salina yang tinggi dan kelemahan utama adalah pada nilai ekonomi Salina. Pada faktor eksternal, ketersediaan tambak di Pantura menjadi peluang utama yang dapat dimanfaatkan dalam usaha pengembangan budidaya Salina dan faktor yang menjadi ancaman utama adalah konsumen/masyarakat daerah Pantura, khususnya Karawang dan sekitarnya kurang berminat terhadap ikan nila berwarna merah. Pemetaan pada matriks IE, menempatkan usaha Salina berada pada kuadran atau sel II. Berdasarkan penilaian AHP, terdapat 3 alternatif strategi teratas yang sesuai untuk diterapkan dalam rangka pengembangan usaha budidaya Salina, yaitu meningkatkan kegiatan promosi dan sosialisasi untuk memperkenalkan Salina sekaligus menarik minat masyarakat dan meningkatkan permintaan; mengembangkan kerjasama dengan industri dan himpunan masyarakat tambak dalam rangka mengoptimalkan pemanfaatan lahan tambak dan penyebaran Salina; dan menjalin kemitraan dengan petani dan memberikan jaminan pasar. 


\section{DAFTAR PUSTAKA}

Altun, T., N. Tekelioglu, D. Danabas. 2006. Tilapia culture and its problems in Turkey. Ege University Press: Journal of Fisheries \& Aquatic Sciences, 23(3-4): 473-478.

Ayuningtyas, S.Q., M.Z. Junior, D.T. Soelistyowati. 2015. Alih Kelamin Jantan Ikan Nila Menggunakan $17 \alpha$-metiltestosteron Melalui Pakan Dan Peningkatan Suhu Jurnal Akuakultur Indonesia, 14(2): 159-163.

Mantau, Z. 2005. Produksi Benih Ikan Nila Jantan Dengan Rangsangan Hormon Metiltestosteron Dalam Tepung Pelet. Jurnal Litbang Pertanian, 24(2): 80-82.

Morita, M., A. Takemura, M. Okuno. 2004. Acclimation of sperm motility apparatus in seawater-acclimated eyryhaline tilapia Oreochromis mossambicus. The Journal of
Experimental Biology 207: 337-345.doi:10. 1242/jeb.00748.

Rahmawaty, S. 2016. Analisis Strategi Pengembangan Usaha Peternakan Domba PT Alam Desa Tapos di Kecamatan Tenjolaya Kabupaten Bogor[tesis]. Bogor (ID): Institut Pertanian Bogor.

Rangkuti, F. 2014. Analisis SWOT: Teknik Membendah Kasus Bisnis. Jakarta (ID): PT Gramedia Pustaka Utama.

Ridha, M.T. 2008. Preliminary Observation on Salinity Tolerance of Three Sizes of the GIFT and Non-Improved Strains of the Nile Tilapia Oreochromis Niloticus. European Journal of Scientific Research Vol.24 No.3: 273-277.

Sismaraini, D. 2015. Strategi Pengembangan Industri Kitin dan Kitosan di Indonesia [tesis]. Bogor (ID): Institut Pertanian Bogor. 